\title{
White Light-Activated Antimicrobial Paint using Crystal Violet
}

\author{
Gi Byoung Hwang ${ }^{a}$, Elaine Allan ${ }^{b}$ and Ivan P. Parkin ${ }^{a *}$ \\ ${ }^{a}$ Materials Chemistry Research Centre, Department of Chemistry, University College \\ London, 20 Gordon Street, London, WC1H OAJ, United Kingdom \\ ${ }^{b}$ Division of Microbial Diseases, UCL Eastman Dental Institute, University College London, \\ 256 Gray's Inn Road, London WC1X 8LD, United Kingdom
}

* To whom correspondence should be addressed.

E-mail: i.p.parkin@ucl.ac.uk Tel: 44(0)207 6794669 


\section{Abstract}

Crystal violet (CV) was incorporated into acrylic latex to produce white light activated antimicrobial paint (WLAAP). Measurement of the water contact angle of the WLAAP showed that the water contact angle increased with increasing $\mathrm{CV}$ concentration. In a leaching test over $120 \mathrm{~h}$, the amount of $\mathrm{CV}$ which leached from the WLAAPs was close to the detection limit $(<0.03 \%)$. The WLAAPs were used to coat samples of polyurethane and these showed bactericidal activity against $E$. coli which is a key causative agent of healthcare-associated infections (HAIs). A reduction in the numbers of viable bacteria was observed on the painted coated polyurethane after $6 \mathrm{~h}$ in the dark and the bactericidal activity increased with increasing $\mathrm{CV}$ concentration $(P<0.1)$. After $6 \mathrm{~h}$ of white light exposure, all of coated polyurethanes demonstrated a potent photobactericidal activity and it was statistically confirmed that the WLAAP showed better activity in white light than in the dark $(P<0.05)$. At the highest CV concentration, the numbers of viable bacteria fell below the detection limit $\left(<10^{3} \mathrm{CFU} / \mathrm{mL}\right)$ after $6 \mathrm{~h}$ of white light exposure. The difference in antimicrobial activity between the materials in the light and dark was $0.48 \log$ at CV $250 \mathrm{ppm}$ and it increased by 0.43 log at each increment of CV $250 \mathrm{ppm}$. The difference was the highest $(>1.8 \mathrm{log})$ at the highest CV concentration (1000 ppm).These WLAAPs are promising candidates for use in healthcare facilities to reduce HAIs.

Keywords: crystal violet, acrylic latex, E.coli bacteria, white light-activated antimicrobial paint, water contact angle 


\section{Introduction}

Healthcare-associated infections (HAIs) occur in surgery centers, dialysis centers, and longterm care facilities such as nursing homes, and community clinics ${ }^{1}$. Their effects vary from simply discomfort for patients to prolonged or permanent disability and in some cases death ${ }^{2}$. According to the US Center of Disease Control and Prevention (CDC) in the US, approximately $4 \%$ of inpatients acquire HAIs, equivalent to 728,000 infections per year, with 75,000 of these patients dying during hospitalization ${ }^{3,4}$.

Since 2008, the CDC has implemented many strategies, including surveillance, inspection, and improved guidelines to reduce the rate of HAIs ${ }^{5-10}$. In particular, significant effort has been dedicated to prevent central line-associated bloodstream infections (CLABSIs), catheterassociated urinary tract infections (CAUTIs), and surgical site infections (SSIs), meticillinresistant Staphylococcus aureus (MRSA) infections, and Clostridium difficile infections. Despite these actions, a reduction in infection rates was often not achieved, and in some cases, even increased ${ }^{11}$.

Contaminated surfaces in healthcare facilities make an important contribution to HAIs. Pathogens are capable of surviving on surfaces of healthcare facilities for several weeks and they can be transmitted through touch by healthcare workers and patients ${ }^{12,13}$. Vigorous cleaning and disinfection schemes can reduce transmission of healthcare associated pathogens 14, 15. However, routine cleaning and disinfection is unable to completely remove the pathogens, which are adhesive and may reproduce rapidly in favourable conditions ${ }^{16,17}$. Thus, it is necessary to develop alternative techniques to prevent or reduce pathogen transmission in healthcare facilities.

Use of antimicrobial surfaces is considered an alternative approach to inhibit the spread of HAIs in healthcare facilities as an additional measure to cleaning ${ }^{18,19}$. Many techniques have 
been suggested for application to soft and hard surfaces, including silver or copper coated surfaces ${ }^{20-22}$, self-cleaning surfaces ${ }^{23,24}$ and enzyme or bacteriophage immobilized surfaces 25, 26. In addition, the incorporation of light-activated antimicrobial agents (LAAAs) into surfaces is considered a promising technique ${ }^{27-29}$. Titanium dioxide $\left(\mathrm{TiO}_{2}\right)$, a well known LAAA, is capable of killing a range of microorganisms including bacteria, fungi, viruses, and algae, and it has been studied for application in medical devices such as film, glass, and polymers ${ }^{30-33}$. The antimicrobial activity of $\mathrm{TiO}_{2}$ is frequently ascribed to $\mathrm{OH}^{-} \cdot$ radicals and other reactive oxygen species (ROS) induced by the light source, causing damage to the bacterial cell membrane and cell wall ${ }^{33}$. However, $\mathrm{TiO}_{2}$ demonstrates negligible photobactericidal activity under white light conditions as it is activated by ultraviolet (UV) light which comprises only a small proportion of the total radiation in sunlight and is virtually absent in artificial white lighting ${ }^{34,35}$. In order to address this problem, many studies was recently performed to enhance photocatalytic efficiency and white light utilization of $\mathrm{TiO}_{2}$ including using impurity dope and metallization ${ }^{36-38}$. Previous studies showed that incorporation of vanadium or silver and bromine extended photocatalytic range of $\mathrm{TiO}_{2}$ from the ultraviolet to the visible region and they showed enhanced antimicrobial activities on bacteria under white light condition ${ }^{39,40}$.

Crystal violet (CV), toluidine blue $\mathrm{O}(\mathrm{TBO})$, and methylene blue (MB) dyes, which are widely used in histological stains and for bacterial classification ${ }^{41,42}$, are also known LAAAs showing photobactericidal activity in white light. The dyes generate singlet oxygen $\left({ }^{1} \mathrm{O}_{2}\right)$ and ROS when they are exposed to the light source ${ }^{43}$, and the ${ }^{1} \mathrm{O}_{2}$ and ROS cause adverse effects in bacteria such as loss of membrane integrity, inactivation of enzymes and DNA damage resulting in cell death ${ }^{44-46}$. The generation of ${ }^{1} \mathrm{O}_{2}$ and ROS is directly related to light intensity 47, 48 . In addition, the dyes have somewhat lower or no antimicrobial activity in the absence of 
light ${ }^{49-51}$. The antimicrobial activity of $\mathrm{CV}, \mathrm{TBO}$, and $\mathrm{MB}$ dyes is dependent on their concentration, the exposure time, and the intensity of the light source ${ }^{52,53}$. Recent studies from our group have investigated the application of $\mathrm{CV}, \mathrm{TBO}$, and $\mathrm{MB}$ dyes to polymers to generate antimicrobial surfaces for use in medical devices including tracheal or urinary catheters and tubes for intravenous drips ${ }^{54,55}$. We have shown that the dyes can be readily impregnated into polymers using a swell-encapsulation-shrink process, and the polymers showed potent photobactericidal activity in white light ${ }^{44}, 55$. In addition, incorporation of gold ( $\left.\mathrm{Au}\right)$ nanoparticles into a dye impregnated polymer significantly enhanced the photobactericidal effect $^{54,56}$.

Although the techniques for synthesis of new materials mentioned above resulted in reasonable antimicrobial activity, most of them involve a multi-step process or long-term treatment for application to surfaces in healthcare facilities, and they are not applicable to all materials. For example, it is difficult for the chemical vapor deposition technique to be applied to heat susceptible materials, and the swell-encapsulation-shrink process can be applied only to soft polymers such as polyurethane and silicon. In the present study, a white light activated antimicrobial paint (WLAAP), which can be easily applied to surfaces in healthcare facilities, was developed. The WLAAP consisted of $\mathrm{CV}$ and a commercial acrylic latex which is commonly used as a component of household paint. The paint was characterized in terms of UV-vis absorbance spectra and water contact angle. The novel WLAAP was used to coat samples of polyether based thermoplastic polyurethane (PTPU) and antibacterial testing of these samples against $E$. coli showed that the WLAAP possessed significant activity in the dark and enhanced activity in the presence of white light.

\section{Materials and Methods}

\subsection{Preparation of light activated antimicrobial paint}


In this study, CV, which is a triarylmethane dye (Figure S1: Supporting information), were used to produce a WLAAP. As shown in Figure 1 (a), 100 mg of CV (Sigma-Aldrich, St. Louis, MO, USA) was dissolved in $10 \mathrm{~mL}$ of DI water and sonicated for 5 min to produce a $\mathrm{CV}$ solution of 10,000 ppm. With stirring for $5 \mathrm{~min}$, the solution was mixed with acrylic latex (X935-33, AzkoNovel, Amsterdam, Netherlands) which is a copolymer of vinyl acetate and butyl acrylate. The CV paint solutions were prepared with various CV concentrations: CV 250, 500, 750, and $1000 \mathrm{ppm}$.

\subsection{Characterization of crystal violet paint}

For characterization of UV-vis spectra and equilibrium water contact angle of the CV paint, $1.5 \mathrm{~mL}$ of the paint was gently injected onto the surface of glass slides $\left(2.5 \times 7.5 \mathrm{~cm}^{2}\right)$, and airdried for $24 \mathrm{~h}$ in the dark. The coating thickness was approximately $0.3 \mathrm{~mm}$. The UV-vis absorption spectra for the paint coated slide glasses were measured using a UV-Vis Spectrometer (PerkinElmer Inc., Winter St., CT, USA). Absorption was measured from 400 to $900 \mathrm{~nm}$.

The equilibrium water contact angle on the paint coated samples was measured. A droplet $(\sim 5 \mu \mathrm{L})$ of deionised water was dropped onto the surface of the samples by gravity from a gauge 27 needle, the samples were photographed side on and the images was analyzed using Surftens 4.5 software.

\subsection{Leaching test}

The stability of CV paint in solution was tested. Polyether based thermoplastic polyurethane (PTPU, American Polyfilm Inc, Branford, CT, USA) samples $\left(1.5 \times 1.5 \mathrm{~cm}^{2}\right)$ were coated by $0.6 \mathrm{~mL}$ of $\mathrm{CV}$ paint, and air dried for $24 \mathrm{~h}$ in the dark. The coated PTPU samples were placed in $5 \mathrm{~mL}$ of PBS solution for $120 \mathrm{~h}$. UV-vis spectra of the solutions were periodically measured to determine if $\mathrm{CV}$ was leaching from the paint into the surrounding solution. The comparison 
of the absorbance at $590 \mathrm{~nm}$ of PBS with a CV calibration curve enabled the determination of the released $\mathrm{CV}$ concentration.

\subsection{Antimicrobial testing}

For antimicrobial testing, the CV paint coated PTPU samples were used. The antimicrobial activities of the samples were tested against E. coli ATCC 25922. The bacteria were stored at $-70^{\circ} \mathrm{C}$ in Brain-Heart-Infusion broth (Oxoid Ltd., Hampshire, England, UK) containing 20\% (v/v) glycerol and propagated on MacConkey agar (Oxoid Ltd., Hampshire, England, UK). 10 $\mathrm{mL}$ of BHI broth was inoculated with one bacterial colony and cultured at $37^{\circ} \mathrm{C}$ with shaking at $200 \mathrm{rpm}$. After incubation for $18 \mathrm{~h}$, the bacteria were harvested by centrifugation $\left(21^{\circ} \mathrm{C}\right.$, $4000 \mathrm{rpm}$ for $20 \mathrm{~min}$ ), washed using $10 \mathrm{~mL}$ of phosphate buffered saline (PBS), and centrifuged again to recover the bacteria which were re-suspended in $10 \mathrm{~mL}$ of PBS. The washed suspension was diluted 1000 -fold in order to obtain $\sim 10^{6}$ colony forming units per millilitre (CFU/mL). As shown in Figure 1 (b), $25 \mu \mathrm{L}$ of bacterial suspension was inoculated on to the surface of each sample and a sterile glass cover slip $\left(2.2 \times 2.2 \mathrm{~cm}^{2}\right)$ was place on top to ensure good contact between the bacteria and the surface of the sample. The samples were loaded into petri dishes containing wet filter paper to maintain humidity, and exposed to white light, while a control set of samples was kept in the dark. After light exposure, the samples were place into $5 \mathrm{~mL}$ of PBS, and mixed using a vortex mixer for $1 \mathrm{~min}$. The bacterial suspension was diluted, plated onto MacConkey agar, and incubated at $37^{\circ} \mathrm{C}$ for 24 hours. The colonies that grew on the plates were counted.

\subsection{Statistical analyses}

Correlation coefficients, linear regressions, and t-statistics of experimental data were calculated using the SPSS statistical software, version 12.0 (SPSS, Inc., Chicago, IL, USA).

\section{Results and discussion}


Various ratios of CV solution and acrylic latex (polymer) were employed to make WLAAPs, as shown Figure 2 (a). The paint changed from white to bright violet by adding CV into the acrylic latex, and the colour became more intense with increasing CV concentration. Figure 2 (b) shows the paint coated glass slides. Glass slides were coated by the paints containing different quantities of $\mathrm{CV}$, and then air-dried for $24 \mathrm{~h}$ in the dark. After drying, the acrylic latex (control) changed from white to colourless, and the CV incorporated paints maintained their violet colour. However, in contrast with the solution state samples, the intensity of the paints did not increase with increasing CV concentration (250 to $750 \mathrm{ppm}$ ).

The UV-vis absorbance spectra of control and CV paints were measured over the wavelengths $400-900 \mathrm{~nm}$. Since the absorbance values of paints containing >CV $250 \mathrm{ppm}$ exceeded the detection limit of the UV-Vis Spectrometer, 10-fold diluted CV paints were used in this measurement. As shown in Figure 3, the colour intensity of the paints appeared lower after dilution. The absorbance spectra showed that all of the CV paints gave a main absorption at $590 \mathrm{~nm}$, and the peak intensity and spectrum range of absorbance increased with $\mathrm{CV}$ concentration. The spectrum curves of the $\mathrm{CV}$ paints were different from the results of previous studies; the absorbance spectrum of the CV paint gave a normal distribution whereas the spectrum of $\mathrm{CV}$ incorporated into polymers presented bimodal distribution ${ }^{54,56}$. This is probably due to difference in the solvents used. Depending on the type of solvent such as water, acetone, and methanol, the $\mathrm{CV}$ absorbance spectrum can change with different peak in the wavelength range of 500-650 $\mathrm{nm}{ }^{57}$. Regardless of the $\mathrm{CV}$ concentration in the paint, all of the paints showed comparable spectra in agreement with results of a previous study ${ }^{58}$.

In order to investigate the change of physical property by combination of crystal violet and acrylic latex, the water contact angle of control and CV paints was measured. As shown in Figure 4, the control gave water contact angles of $10.9^{\circ}$. However, the contact angle increased 
with CV concentration $\left(y=0.0042 x+10.449, R^{2}=0.8487\right)$, and it was the highest at CV 1000 ppm. Compared to the control, the highest increase was approximately $4.2^{\circ}$ at the highest $\mathrm{CV}$ concentration $(P<0.01)$. This is explained by the fact that the increase of the $\mathrm{CV}$ portion in acrylic latex contributed to the change of water contact angle because CV is a relatively hydrophobic compared to the acrylic latex (control).

The CV release from the CV paint in PBS solution was determined using a UV-vis spectrometer. The CV paint coated PTPU samples were immersed in $5 \mathrm{~mL}$ of PBS solution for a total of $120 \mathrm{~h}$ and the $\mathrm{CV}$ release was measured at intervals of $24 \mathrm{~h}$. Figure 5 shows the CV release from the paint coated samples to PBS solutions for $120 \mathrm{~h}$. It was confirmed that all of paints released some $\mathrm{CV}$ into PBS solution after $24 \mathrm{~h}$ immersion and that the $\mathrm{CV}$ concentration was the highest $(0.27 \mathrm{ppm})$ for the paint containing CV $1000 \mathrm{ppm}(0.04,0.07$, and $0.14 \mathrm{ppm}$ from paints containing CV 250, 500, and $750 \mathrm{ppm}$, respectively). Over a period of more than $100 \mathrm{~h}$, additional CV leaching was not detected in all of the CV paints. The total amount of CV leached from the paints over a period of $120 \mathrm{~h}$ was minor $(<0.03 \%)$.

The antimicrobial testing of CV paint under white light and dark conditions was conducted against Escherichia coli which is a key causative agent of HAIs. $25 \mu \mathrm{L}$ of this bacterial suspension, containing $7.8 \times 10^{4} \mathrm{CFU}$, was inoculated on to the surface of $\mathrm{CV}$ paint coated PTPU and then exposed to white light or placed in the dark at $20^{\circ} \mathrm{C}$ for $6 \mathrm{~h}$. The intensity of white light was measured at a distance of $30 \mathrm{~cm}$ from the lamp using a lux meter (LX-101, Lutron Inc., Coopersburg, PA, USA). The light intensity was the highest at the center and it decreased with increasing distance from the center. The intensity of the light ranged from 3900 to 5300 lux (Figure S2).

CV dye used in this study as WLAAA has antimicrobial and antifungal activities. It inhibits bacterial growth through interaction between positive $\left(\mathrm{GV}^{+}\right)$ions dissociated from $\mathrm{CV}$ and 
components of bacterial cells including lipopolysaccharide in the outer membrane of Gram negative bacteria, peptidoglycan and DNA ${ }^{50,59}$. As shown in Figure 6 (a), the combination of $\mathrm{CV}$ and acrylic latex showed antimicrobial activity in the dark. After $6 \mathrm{~h}$ in the dark, a $0.12 \log$ reduction in the numbers of viable bacteria was observed for CV $250 \mathrm{ppm}$, compared with the control, and the numbers of viable bacteria decreased with increasing $\mathrm{CV}$ concentration $\left(\mathrm{R}^{2}=\right.$ $0.996, P<0.1)$ in the paint: 0.31 and $0.49 \log$ reductions were obtained at CV 500 and $750 \mathrm{ppm}$, respectively, and at CV $1000 \mathrm{ppm}$, a 1.21 log reduction in the numbers of viable bacteria was observed. These results indicate that CV keeps its intrinsic antimicrobial property after being mixed with acrylic latex.

Figure 6 (b) shows the antimicrobial activities of CV paint in white light. As in the dark, the reduction in the numbers of viable bacteria remaining increased with increasing $\mathrm{CV}$ concentration after $6 \mathrm{~h}$ white light exposure $\left(\mathrm{R}^{2}=0.811, P<0.1\right)$. However, there was a statistically significant difference in the total bactericidal activity displayed by the materials in the light compared to the dark (comparison of all the concentrations in the light and dark: $P$ $<0.05)$. After $6 \mathrm{~h}$ of white light exposure, compared with the control, 0.36, 0.43, and $0.86 \mathrm{log}$ reductions in the numbers of viable bacteria were observed at CV 250,500, $750 \mathrm{ppm}$, and at CV $1000 \mathrm{ppm}$, the numbers of viable bacteria fell below the detection limit $\left(<10^{3} \mathrm{CFU} / \mathrm{mL}\right)$. Further, the difference in antimicrobial activity between the materials in the light and dark increased with increasing $\mathrm{CV}$ concentration in the paint. The difference was $0.48 \log$ at $\mathrm{CV}$ $250 \mathrm{ppm}$ and it increased by $0.43 \mathrm{log}$ at each increment of CV $250 \mathrm{ppm}$. The difference between white light and dark conditions was the highest $(>1.8 \mathrm{log})$ at the highest $\mathrm{CV}$ concentration (1000 ppm).

The increase in antibacterial activity of the $\mathrm{CV}$ paint in white light can be explained as follows: upon white light irradiation of $\mathrm{CV}$ paint, $\mathrm{CV}$ molecules inside the paint are excited to 
a triplet state via an intersystem crossing from a slightly higher energy, shorter lived excited singlet state. The triplet state dye molecules can undergo one of two photochemical pathways ${ }^{44}$; quenching by molecular oxygen including the production of singlet oxygen $\left({ }^{1} \mathrm{O}_{2}\right)$, or interaction with biomolecules in the vicinity generating radical species. The generated ${ }^{1} \mathrm{O}_{2}$ and radical species can initiate multi-site attack on bacteria in the vicinity effecting cell death ${ }^{55}$.

Although previous techniques have showed a good antibacterial activity when applied to surfaces, these techniques, including chemical vapor deposit, swell encapsulation shrink, and physiochemical modification, are not applicable to all substrates. WLAAP developed in this study can be easily applied for a wide range of substrates including paper, metal, glass, and hard and soft polymers (Figure S3). Moreover, WLAAP is readily fabricable and surface treatment using WLAAP is simple and easy. It is expected that WLAAP could be used for clinical care facilities including surgery centers, dialysis centers, and nursing homes and also applied in the home for decoration, and in toilet and kitchen surfaces. For real world application, adverse effects of the paint should be considered. CV has been widely used in medicine for over 100 years ${ }^{50}$. It poses a very low toxicity risk even in case of administration of high quantities ${ }^{50,60}$, however, it has been used in a diluted form as an antiseptic for external wounds for a century. Previous studies showed that CV is a useful agent for the elimination of MRSA on the skin ${ }^{61,62}$, and it did not produce any serious side effects or mild skin irritation ${ }^{62}$. The WLAAP showed it in solution leaching test that $<0.28 \mathrm{ppm}$ of $\mathrm{CV}$ was released from paints containing CV 250, 500, 750, $1000 \mathrm{ppm}$. This is much less than the concentration (lethal dose 50\%: $420 \mathrm{ppm}$ ) representing a toxicity in rat oral test ${ }^{63}$. Moreover, the amount of CV used in WLAAP was relative minor compared to the concentration $(20,000 \mathrm{ppm})$ causing dermal irritation or sensitization in long term clinical assessment ${ }^{64}$. Thus, it is unlikely that the WLAAP we report here will show toxicity towards humans. 


\section{Conclusion}

In this study, CV was incorporated into acrylic latex which is commonly used in household paint to produce WLAAP for healthcare or household applications. The combination of CV and acrylic latex resulted in a potent WLAAP that not only induced the lethal photosensitization (below detection limit at $\mathrm{CV} 1000 \mathrm{ppm}$ ) of $E$. coli within $6 \mathrm{~h}$, but demonstrated strong bactericidal activity (1.21 log reduction in the numbers of viable bacteria at CV $1000 \mathrm{ppm})$ in the dark. Moreover, the CV in the WLAAP was shown to be stable over a $120 \mathrm{~h}$ period showing minimal leaching into the surrounding solution. It is anticipated that this potent WLAAP will be useful in healthcare applications to reduce surface bacterial contamination and thus the incidence of HAIs.

In this study, we did not investigate the amount of generated ${ }^{1} \mathrm{O}_{2}$ and ROS when WLAAP is exposed to what light source, and that which wavelength maximizes the generation. This is important to maximize the antimicrobial efficiency of WLAAP under light condition. Thus, we are considering an experiment of quantum efficiency measurement in future study.

\section{Supporting information}

Figure S1. Chemical structure of crystal violet.

Figure S2. Intesity distribution of white light.

Figure S3. Image of white light-activated antimicrobial paint coated metal, glass paper, and polymers. 


\section{References}

(1) California department of public health. Healthcare-Associated Infections in California Hospitals Annual Report, 2013: Key Findings and Public Health Actions; 2013.

(2) National audit office. Reducing Healthcare Associated Infection in Hospitals in England; House of commons public accounts committee 2009.

(3) Magill, S. S.; Edwards, J. R.; Bamberg, W.; Beldavs, Z. G.; Dumyati, G.; Kainer, M. A.; Lynfield, R.; Maloney, M.; McAllister-Hollod, L.; Nadle, J.; Ray, S. M.; Thompson, D. L.; Wilson, L. E.; Fridkin, S. K.; Emerging Infections Program Healthcare-Associated, I.; Antimicrobial Use Prevalence Survey, T., Multistate Point-Prevalence Survey of Health Care-Associated Infections. N. Engl. J. Med. 2014, 370, 1198-1208.

(4) Douglas Scott II, R. The Direct Medical Costs of Healthcare-Associated Infections in US Hospitals and The Benefits of Prevention 2009; The Division of Healthcare Quality Promotion, National Center for Preparedness, Detection, and Control of Infectious Diseases, Coordinating Center for Infectious Diseases, Centers for Disease Control and Prevention, 2009.

(5) Dudeck, M. A.; Horan, T. C.; Peterson, K. D.; Allen-Bridson, K.; Morrell, G. C.; Pollock, D. A.; Edwards, J. R., National Healthcare Safety Network (NHSN) report, data summary for 2009, device-associated module. Am. J. Infect. Control 2011, 39, 349-367.

(6) Hocevar, S. N.; Fridkin, S.; Edwards, J. R.; Nadle, J.; Janelle, S. J.; Rodriguez, R.; Ray, S. M.; Richards, K.; Lynfield, R.; Thompson, D.; Dumyati, G.; Beldavs, Z. G.; Kainer, M. A.; Magill, S. S., Epidemiology of Pediatric Healthcare-Associated Infections and Antimicrobial Use in U.S. Acute Care Hospitals. ID week 2013, Poster, 297.

(7) Rutal, W. A.; Weber, D. J.; Weinstei, R. A.; Siegel, J. D.; Pearson, M. L.; Chinn, R. Y. W.; DeMaria, A.; Lee, J. T.; Rutala, W. A.; Scheckler, W. E.; Stover, B. H.; Underwood, M. A. Guideline for Disinfection and Sterilization in Healthcare Facilities; Centers for Disease Control and Prevention (CDC), 2008.

(8) Dudeck, M. A.; Horan, T. C.; Peterson, K. D.; Allen-Bridson, K.; Morrell, G.; Pollock, D. A.; Edwards, J. R., National Healthcare Safety Network (NHSN) Report, Data Summary for 2010, Device-Associated Module. Am. J. Infect. Control 2011, 39, 798-816.

(9) Dudeck, M. A.; Horan, T. C.; Peterson, K. D.; Allen-Bridson, K.; Morrell, G.; Anttila, A.; Pollock, D. A.; Edwards, J. R., National Healthcare Safety Network Report, Data Summary for 2011, Device-Associated Module. Am. J. Infect. Control 2013, 41, 286-300.

(10) Dudeck, M. A.; Edwards, J. R.; Allen-Bridson, K.; Gross, C.; Malpiedi, P. J.; Peterson, K. D.; Pollock, D. A.; Weiner, L. M.; Sievert, D. M., National Healthcare Safety Network Report, Data Summary for 2013, Device-associated Module. Am. J. Infect. Control 2015, 43, 206-221.

(11) Centers for Disease Control and Prevention (CDC) National and State Healthcare Associated Infections Progress Report; 2015.

(12) Ayliffe, G. A. J.; Collins, B. J.; Lowbury, E. J. L.; Babb, J. R.; Lilly, H. A., Ward floors and Other Surfaces as Reservoirs of Hospital Infection. J. Hyg. 2009, 65, 515.

(13) Boyce, J. M., Environmental Contamination Makes An Important Contribution to Hospital Infection. J. Hosp. Infect. 2007, 65, 50-54.

(14) Hall, L. B.; Hartnett, M. J., Measurement of the Bacterial Contamination on Surfaces in Hospitals. Public Health Rep. 1964, 79, 1021-1024.

(15) Singh, D.; Kaur, H.; Gardner, W. G.; Treen, L. B., Bacterial Contamination of Hospital Pagers. Infect. Control Hosp. Epidemiol. 2002, 23, 274-276.

(16) Ratkowsky, D. A.; Olley, J.; McMeekin, T. A.; Ball, A., Relationship Between Temperature and Growth Rate of Bacterial Cultures. J. Bacteriol. 1982, 149,1-5.

(17) Page, K.; Wilson, M.; Mordan, N. J.; Chrzanowski, W.; Knowles, J.; Parkin, I. P., Study of The Adhesion of Staphylococcus aureus to Coated Glass Substrates. J. Mater. Sci. 2011, 46, 6355-6363.

(18) Hasan, J.; Crawford, R. J.; Ivanova, E. P., Antibacterial Surfaces: The Quest for A New Generation of Biomaterials. Trends biotechnol. 2013, 31, 295-304.

(19) Campoccia, D.; Montanaro, L.; Arciola, C. R., A Review of The Biomaterials Technologies for 
Infection-Resistant Surfaces. Biomaterials 2013, 34, 8533-8554.

(20) Chen, X.; Schluesener, H. J., Nanosilver: A Nanoproduct in Medical Application. Toxicol. Lett. 2008, 176, 1-12.

(21) Roe, D.; Karandikar, B.; Bonn-Savage, N.; Gibbins, B.; Roullet, J. B., Antimicrobial Surface Functionalization of Plastic Catheters by Silver Nanoparticles. J. Antimicrob. Chemother. 2008, 61, 869-876.

(22) Hassan, I. A.; Parkin, I. P.; Nair, S. P.; Carmalt, C. J., Antimicrobial Activity of Copper and Copper(i) Oxide Thin Films Deposited via Aerosol-Assisted CVD. J. Mater. Chem. B 2014, 2, 2855.

(23) Lu, Y.; Sathasivam, S.; Song, J.; Crick, C. R.; Carmalt, C. J.; Parkin, I. P., Robust Self-Cleaning Surfaces That Function When Exposed to Either Air or Oil. Science 2015, 347, 1132-1135.

(24) Okada, A.; Nikaido, T.; Ikeda, M.; Okada, K.; Yamauchi, J.; Foxton, R. M.; Sawada, H.; Tagami, J.; Matin, K., Inhibition of Biofilm Formation Using Newly Developed Coating Materials with Self-Cleaning Properties. Dent. Mater. J. 2008, 27, 565-572.

(25) Pangule, R. C.; Brooks, S. J.; Dinu, C. Z.; Bale, S. S.; Salmon, S. L.; Zhu, G.; Metzger, D. W.; Kane, R. S.; Dordick, J. S., Antistaphylococcal Nanocomposite Films Based on Enzyme-Nanotube Conjugates. ACS Nano 2010, 4, 3993-4000.

(26) Markoishvili, K.; Tsitlanadze, G.; Katsarava, R.; Glenn, J.; Sulakvelidze, A., A Novel SustainedRelease Matrix Based on Biodegradable Poly(Ester Amide)s and Impregnated with Bacteriophages and An Antibiotic Shows Promise in Management of Infected Venous Stasis Ulcers and Other Poorly Healing Wounds. Int. J. Dermatol. 2002, 41, 453-458.

(27) Perni, S.; Piccirillo, C.; Pratten, J.; Prokopovich, P.; Chrzanowski, W.; Parkin, I. P.; Wilson, M., The Antimicrobial Properties of Light-Activated Polymers Containing Methylene Blue and Gold Nanoparticles. Biomaterials 2009, 30, 89-93.

(28) Perni, S.; Prokopovich, P.; Piccirillo, C.; Pratten, J.; Parkin, I. P.; Wilson, M., Toluidine BlueContaining Polymers Exhibit Potent Bactericidal Activity When Irradiated with Red Laser Light. J. Mater. Chem. 2009, 19, 2715-2723.

(29) Rai, M.; Yadav, A.; Gade, A., Silver Nanoparticles as A New Generation of Antimicrobials. Biotechnol. Adv. 2009, 27, 76-83.

(30) Zhao, L.; Chu, P. K.; Zhang, Y.; Wu, Z., Antibacterial Coatings on Titanium Implants. J. Biomed. Mater. Res. B Appl. Biomater. 2009, 91, 470-480.

(31) Daoud, W. A.; Xin, J. H.; Zhang, Y.-H., Surface Functionalization of Cellulose Fibers with Titanium Dioxide Nanoparticles and Their Combined Bactericidal Activities. Surf. Sci. 2005, 599, 69-75.

(32) Visai, L.; De Nardo, L.; Punta, C.; Melone, L.; Cigada, A.; Imbriani, M.; Arciola, C. R., Titanium Oxide Antibacterial Surfaces in Biomedical Devices. Int. J. Artif. Organs 2011, 34, 929-946.

(33) Foster, H. A.; Ditta, I. B.; Varghese, S.; Steele, A., Photocatalytic Disinfection Using Titanium Dioxide: Spectrum and Mechanism of Antimicrobial Activity. Appl. Microbiol. Biotechnol. 2011, 90, 1847-1868.

(34) Fujishima, A.; Rao, T. N.; Tryk, D. A., Titanium Dioxide Photocatalysis. J. Photoch. Photobio. C 2000, $1,1-21$.

(35) Dunnill, C. W.; Page, K.; Aiken, Z. A.; Noimark, S.; Hyett, G.; Kafizas, A.; Pratten, J.; Wilson, M.; Parkin, I. P., Nanoparticulate Silver Coated-Titania Thin Films-Photo-Oxidative Destruction of Stearic Acid under Different Light Sources and Antimicrobial Effects under Hospital Lighting Conditions. J. Photoch. Photobio. A 2011, 220, 113-123.

(36) Zhang, L.; Yu, J. C.; Yip, H. Y.; Li, Q.; Kwong, K. W.; Xu, A.-W.; Wong, P. K., Ambient Light Reduction Strategy to Synthesize Silver Nanoparticles and Silver-Coated $\mathrm{TiO}_{2}$ with Enhanced Photocatalytic and Bactericidal Activities. Langmuir 2003, 19, 10372-10380.

(37) Sunada, K.; Watanabe, T.; Hashimoto, K., Bactericidal Activity of Copper-Deposited $\mathrm{TiO}_{2}$ Thin Film under Weak UV Light Illumination. Environ. Sci. Technol. 2003, 37, 4785-4789.

(38) Stathatos, E.; Lianos, P.; Falaras, P.; Siokou, A., Photocatalytically Deposited Silver Nanoparticles on Mesoporous $\mathrm{TiO}_{2}$ Films. Langmuir 2000, 16, 2398-2400.

(39) Elahifard, M. R.; Rahimnejad, S.; Haghighi, S.; Gholami, M. R., Apatite-Coated Ag/AgBr/TiO 2 
Visible-Light Photocatalyst for Destruction of Bacteria. J. Am. Chem. Soc. 2007, 129, 9552-9553.

(40) Fu, G.; Vary, P. S.; Lin, C. T., Anatase $\mathrm{TiO}_{2}$ nanocomposites for antimicrobial coatings. J. Phys. Chem. B 2005, 109, 8889-8898.

(41) Cohen, A. S.; Calkins, E.; Levene, C. I., Studies on Experimental Amyloidosis I. Analysis of Histology and Staining Reactions of Casein-Induced Amyloidosis in The Rabbit. Am. J. Pathol. 1959, 35, 971-989.

(42) Yang, Y.-I.; Jung, D.-W.; Bai, D.-G.; Yoo, G.-S.; Choi, J.-K., Counterion-Dye Staining Method for DNA in Agarose Gels Using Crystal Biolet and Methyl Orange. Electrophoresis 2001, 22, 855-859.

(43) Maisch, T., Anti-Microbial Photodynamic Therapy: Useful in The Future? Lasers Med. Sci. 2007, 22, 83-91.

(44) Noimark, S.; Dunnill, C. W.; Kay, C. W. M.; Perni, S.; Prokopovich, P.; Ismail, S.; Wilson, M.; Parkin, I. P., Incorporation of Methylene Blue and Nanogold into Polyvinyl Chloride Catheters; A New Approach for Light-Activated Disinfection of Surfaces. J. Maters. Chem. 2012, 22, 15388.

(45) Ben-Hur, E.; Moor, A. C. E.; Margolis-Nunno, H.; Gottlieb, P.; Zuk, M. M.; Lustigman, S.; Horowitz, B.; Brand, A.; Van Steveninck, J.; Dubbelman, T. M. A. R., The Photodecontamination of Cellular Blood Components: Mechanisms and Use of Photosensitization in Transfusion Medicine. Transfus. Med. Rev. 1996, 10, 15-22.

(46) Oleinick, N. L.; Evans, H. H., The Photobiology of Photodynamic Therapy: Cellular Targets and Mechanisms. Radiat. Res. 1998, 150, S146.

(47) Naik, A. J. T.; Ismail, S.; Kay, C.; Wilson, M.; Parkin, I. P., Antimicrobial Activity of Polyurethane Embedded with Methylene Blue, Toluidene Blue and Gold Nanoparticles against Staphylococcus aureus; Illuminated with White Light. Mater. Chem. Physi. 2011, 129, 446-450.

(48) Piccirillo, C.; Perni, S.; Gil-Thomas, J.; Prokopovich, P.; Wilson, M.; Pratten, J.; Parkin, I. P., Antimicrobial Activity of Methylene Blue and Toluidine Blue O Covalently Bound to A Modified Silicone Polymer Surface. J. Mater. Chem. 2009, 19, 6167.

(49) Maley, A. M.; Arbiser, J. L., Gentian Violet: A 19th Century Drug Re-Emerges in The 21st Century. Exp. Dermatol. 2013, 22, 775-780.

(50) Docampo, R.; Moreno, S. N., The Metabolism and Mode of Action of Gentian Violet. Drug Metab. Rev. 1990, 22, 161-178.

(51) Komerik, N.; Wilson, M., Factors Influencing The Susceptibility of Gram-Negative Bacteria to Toluidine Blue O-Mediated Lethal Photosensitization. J. Appl. Microbiol. 2002, 92, 618-623.

(52) Souza, R. C.; Junqueira, J. C.; Rossoni, R. D.; Pereira, C. A.; Munin, E.; Jorge, A. O., Comparison of The Photodynamic Fungicidal Efficacy of Methylene Blue, Toluidine Blue, Malachite Green and Low-Power Laser Irradiation Alone against Candida albicans. Lasers Med. Sci. 2010, 25, 385389.

(53) Noimark, S.; Weiner, J.; Noor, N.; Allan, E.; Williams, C. K.; Shaffer, M. S. P.; Parkin, I. P., DualMechanism Antimicrobial Polymer-ZnO Nanoparticle and Crystal Violet-Encapsulated Silicone. Adv. Funct. Mater. 2015, 25, 1367-1373.

(54) Noimark, S.; Allan, E.; Parkin, I. P., Light-Activated Antimicrobial Surfaces with Enhanced Efficacy Induced by A Dark-Activated Mechanism. Chem. Sci. 2014, 5, 2216.

(55) Ozkan, E.; Allan, E.; Parkin, I. P., The Antibacterial Properties of Light-Activated Polydimethylsiloxane Containing Crystal Violet. RSC Adv. 2014, 4, 51711-51715.

(56) Noimark, S.; Bovis, M.; MacRobert, A. J.; Correia, A.; Allan, E.; Wilson, M.; Parkin, I. P., Photobactericidal Polymers; The Incorporation of Crystal Violet and Nanogold into Medical Grade Silicone. RSC Adv. 2013, 3, 18383.

(57) Korppi-Tommola, J.; Yip, R. W., Solvent Effects on The Visible Absorption Spectrum of Crystal Violet. Can. J. Chem. 1981, 59, 191-194.

(58) Al-Kadhemy, M. F. H.; Abaas, W. H., Absorption and Fluorescence Spectra of Crystal Violet Doped PS and PMMA Blend Films. Atti della Fondazione Giorgio Ronchi 2012, 67, 735.

(59) $\mathrm{Si}$, W. H.; Zi, Y. Q., Studies on The Interaction between RNA with Methyl Violet and Determination of RNA by Spectrophotometry. Guang Pu Xue Yu Guang Pu Fen Xi 2005, 25, 1846-1849.

(60) Drinkwater, P., Gentian Violet — Is It Safe? Aust. N Z J Obstet. Gynaecol. 1990, 30, 65-66.

(61) Kawamoto, K.; Senda, N.; Shimada, K.; Ito, K.; Hirano, Y.; Murai, S., Antibacterial Effect of 
Yellow He-Ne Laser Irradiation with Crystal Violet Solution on Porphyromonas Gingivalis: An Evaluation Using Experimental Rat Model Involving Subcutaneous Abscess. Lasers Med. Sci. 2000, $15,257-262$.

(61) Saji, M.; Taguchi, S.; Uchiyama, K.; Osono, E.; Hayama, N.; Ohkuni, H., Efficacy of Gentian Violet in The Eradication of Methicillin-Resistant Staphylococcus aureus from Skin Lesions. $J$. Hosp. Infect. 1995, 31, 225-228.

(62) National Center for Biotechnology Information, U.S. National Library of Medicine, Crystal Violet, Compound CID 110572015

(63) Diamante, C.; Bergfeld, W. F.; Belsito, D. V.; Klaassen, C. D.; Marks, J. G., Jr.; Shank, R. C.; Slaga, T. J.; Snyder, P. W.; Alan Andersen, F., Final Report on The Safety Assessment of Basic Violet 1, Basic Violet 3, and Basic Violet 4. Int. J. Toxicol. 2009, 28, 193S-204S. 


\section{Figure legends}

Figure 1. (a) Preparation of white light activated antimicrobial paint and (b) antimicrobial testing.

Figure 2. (a) Control and crystal violet paint solutions, and (b) the paint coated glass slides

Figure 3. UV-vis absorption spectra of control and crystal violet paints. The paints containing crystal violet $0,25,50,75$, and $100 \mathrm{ppm}$ were coated to glass slides, and they were measured within the wavelengths $400-900 \mathrm{~nm}$.

Figure 4. Water contact angles on the paints containing crystal violet 250, 500, 750, and 1000 $\mathrm{ppm}$. The paints were coated to polyurethane samples $\left(1.5 \times 1.5 \mathrm{~cm}^{2}\right)$ and water contact angles, and then water contact angle on them were measured.

Figure 5. Leaching testing of crystal violet paints in PBS solution. The paints were coated to polyurethane samples $\left(1.5 \times 1.5 \mathrm{~cm}^{2}\right)$. The samples were immersed in $5 \mathrm{~mL}$ of PBS for $120 \mathrm{~h}$.

Figure 6. Antimicrobial activities of control and crystal violet paints on E. coli bacteria: (a) 6 $\mathrm{h}$ incubation in the dark, and (b) $6 \mathrm{~h}$ incubation in white light. Polyurethane samples $(1.5 \times 1.5$ $\mathrm{cm}^{2}$ ) were coated using crystal violet paint. E coli was placed in contact with the samples and exposed to light intensity ranging from 3900 to 5300 lux. In all tests, the temperature was maintained at a constant $20^{\circ} \mathrm{C}$ in an incubator.

Figure S1. Chemical structure of crystal violet

Figure S2. Intensity distribution of white light which the paint coated samples are irradiated to. The intensity was measured at a distance of $30 \mathrm{~cm}$ from $28 \mathrm{~W}$ hospital fluorescent lamp using a lux meter. Colour scale bar corresponds from low (light blue) to high light intensity (light purple).

Figure S3. White light-activated antimicrobial paint coated (a) metal (aluminum), (b) glass, (c) paper (d) hard polymer (polystyrene), and soft polymer (polyurethane) plates. 


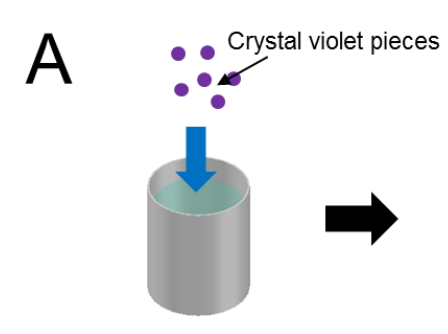

Dissolution of crystal violet Mixing of crystal violet solution in DI water

B

Inoculation of bacteria

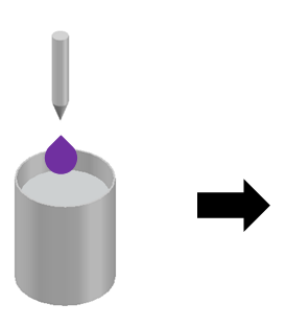
and acrylic latex

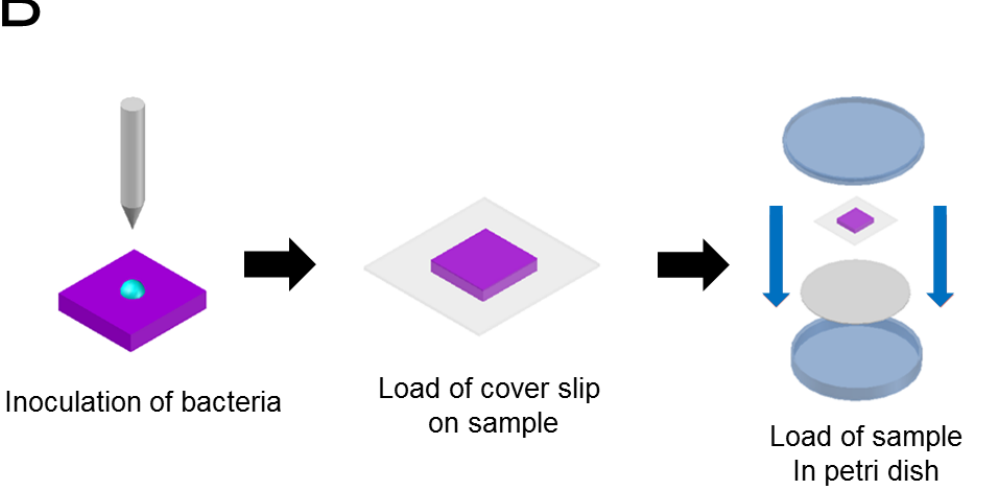

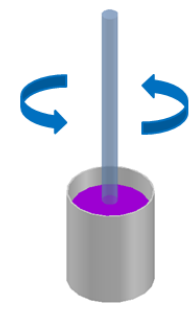

Stir for 5 min

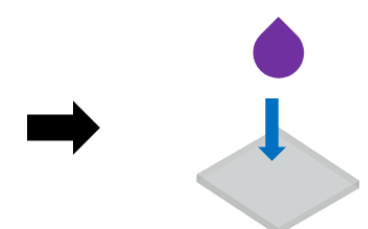

Coating of paint on polymer and dry for $24 \mathrm{~h}$ at dark room

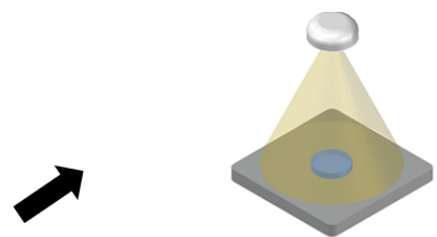

White light exposure on sample

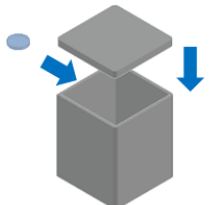

Load of sample in dark room

Figure 1. (a) Preparation of white light activated antimicrobial paint and (b) antimicrobial testing. 

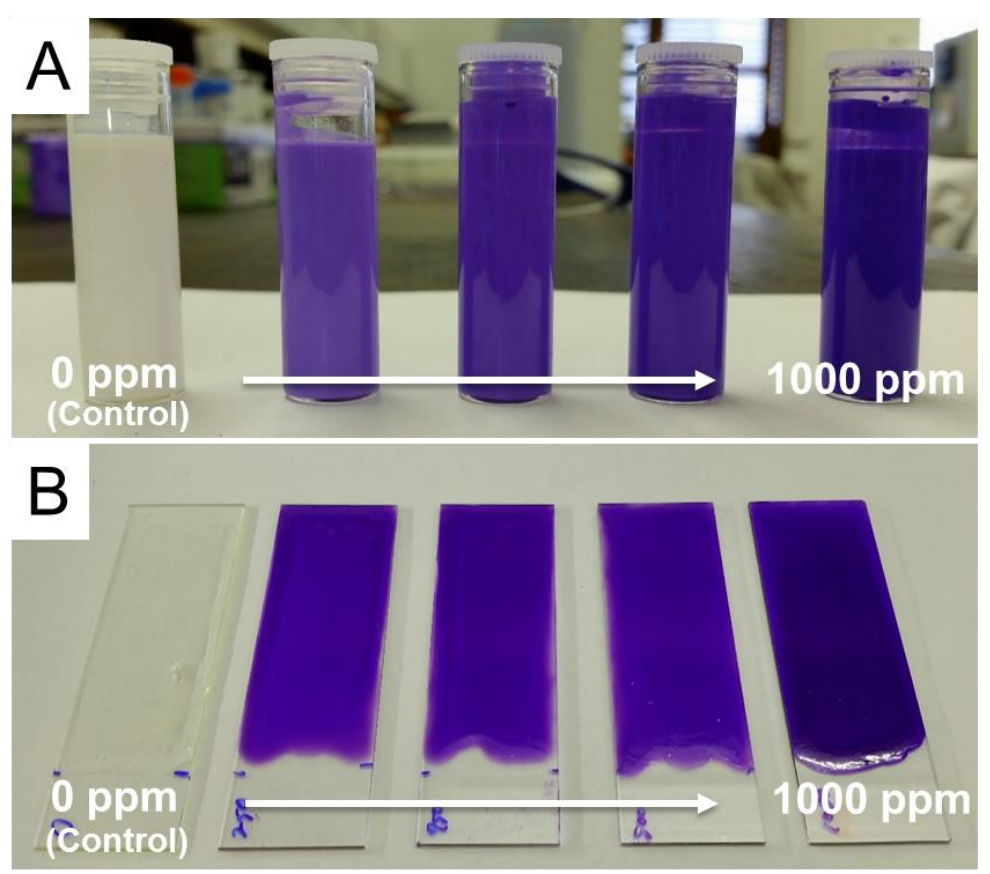

Figure 2. (a) Control and crystal violet paint solutions, and (b) the paint coated glass slides 


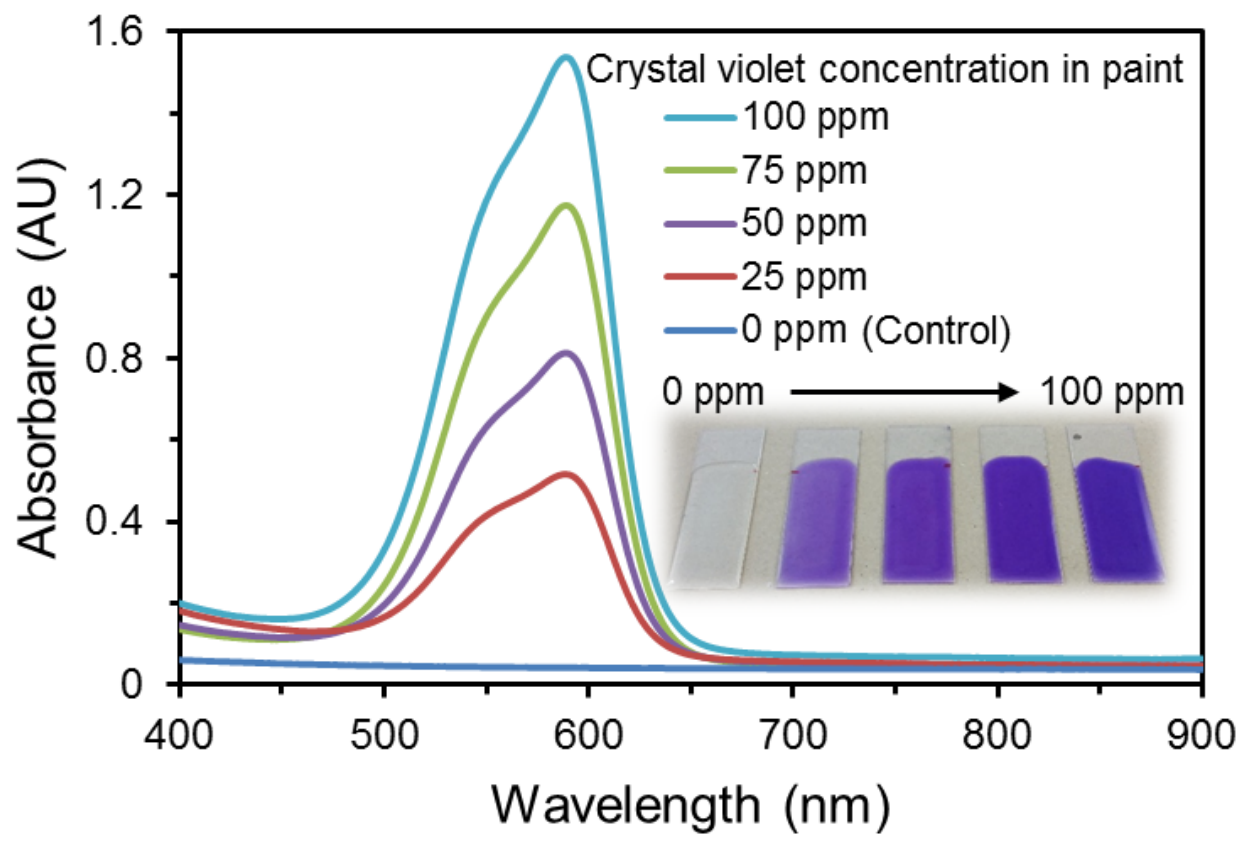

Figure 3. UV-vis absorption spectra of control and crystal violet paints. The paints containing crystal violet $0,25,50,75$, and 100 ppm were coated to glass slides, and they were measured within the wavelengths 400-900 $\mathrm{nm}$. 


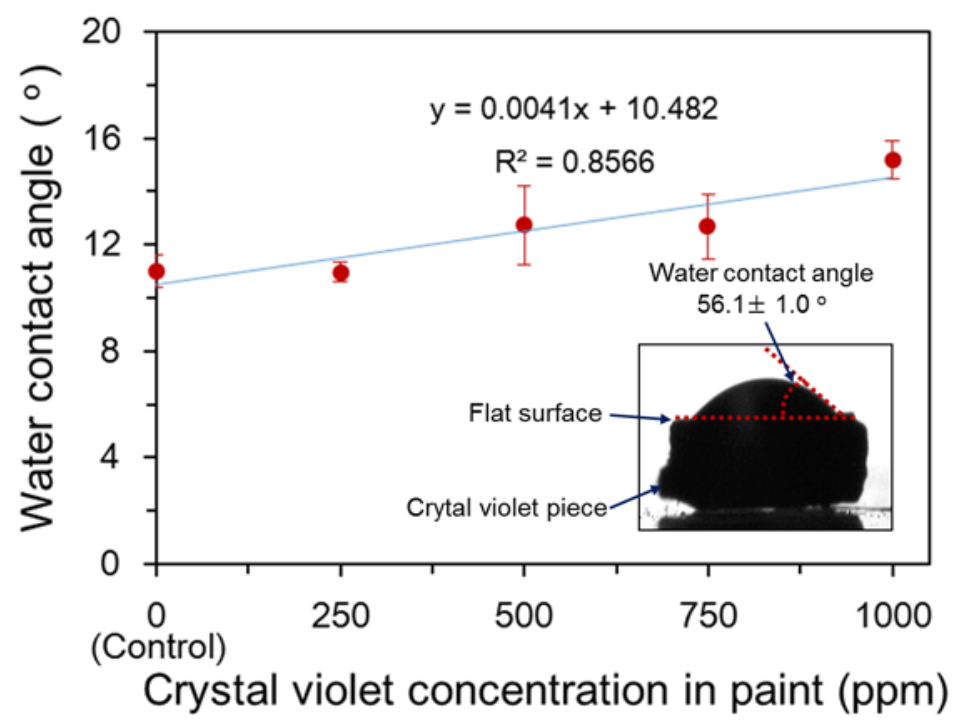

Figure 4. Water contact angles on the paints containing crystal violet $250,500,750$, and 1000 ppm. The paints were coated to polyurethane samples $\left(1.5 \times 1.5 \mathrm{~cm}^{2}\right)$ and water contact angles, and then water contact angle on them were measured. 


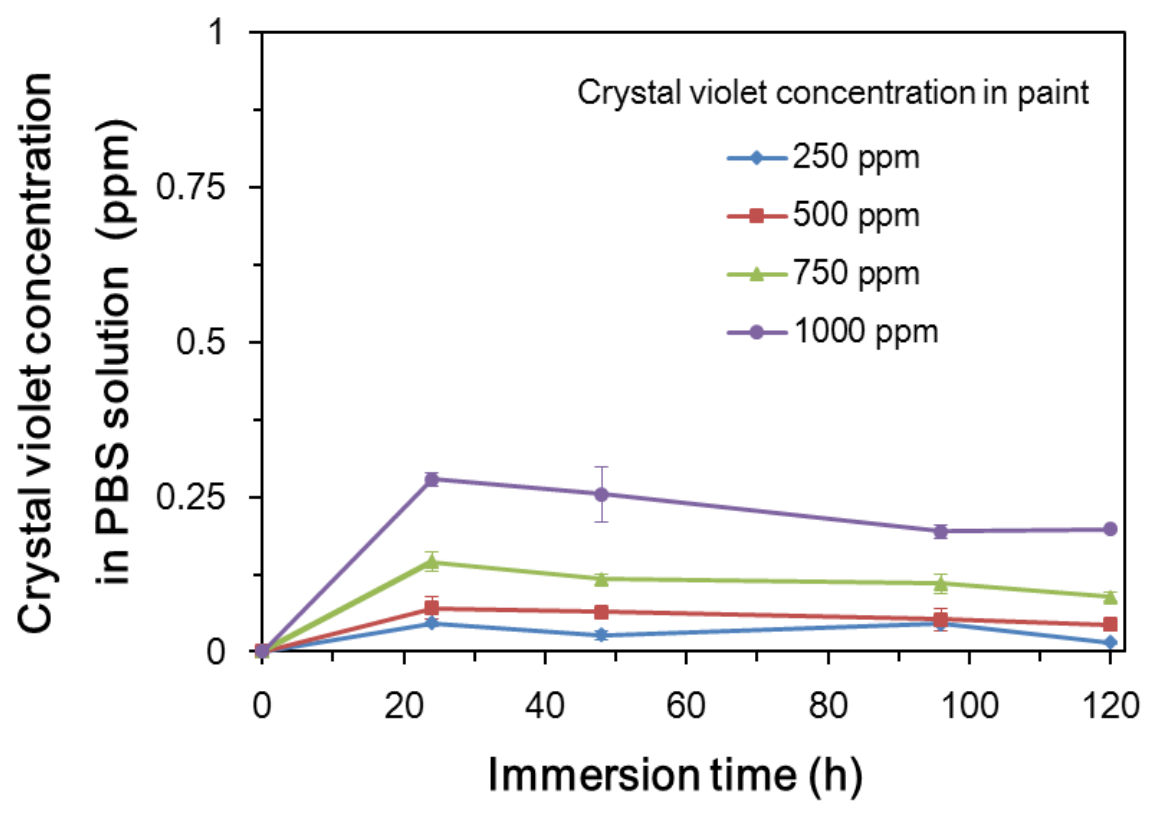

Figure 5. Leaching of $\mathrm{CV}$ from paints into PBS solution. The paints were coated on to polyurethane samples $\left(1.5 \times 1.5 \mathrm{~cm}^{2}\right)$ which were immersed in $5 \mathrm{~mL}$ of PBS for $120 \mathrm{~h}$. 

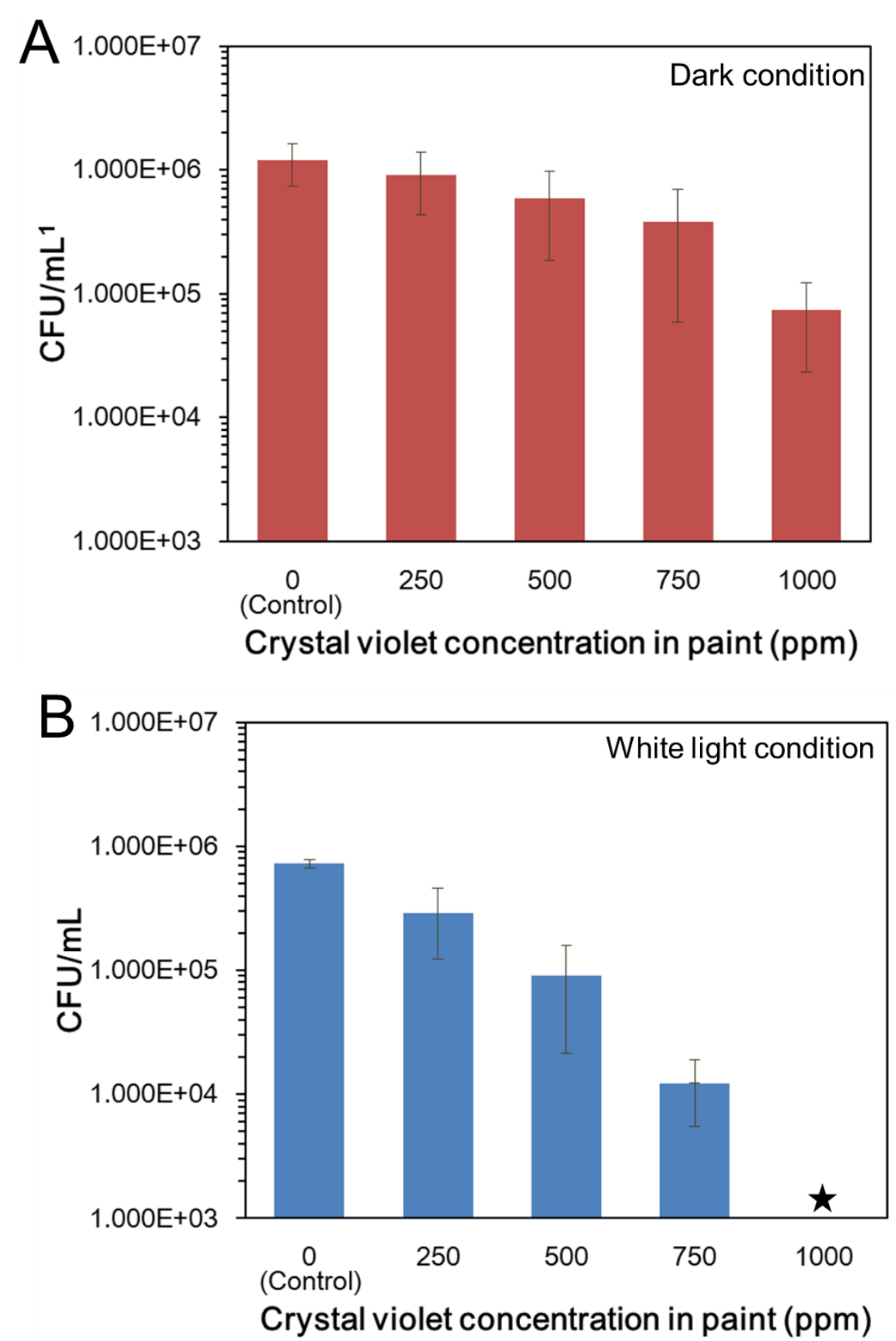

Figure 6. Antimicrobial activity of control and crystal violet paints against E. coli: (a) $6 \mathrm{~h}$ incubation in the dark, and (b) $6 \mathrm{~h}$ incubation in white light. Polyurethane samples $(1.5 \times 1.5$ $\mathrm{cm}^{2}$ ) was coated using crystal violet paints. E coli was placed in contact with the samples and exposed to light intensity ranging from 3900 to 5300 lux. In all tests, the temperature was maintained at a constant $20^{\circ} \mathrm{C}$.

${ }^{1}$ Colony forming unit/ $\mathrm{mL}$

$\star$ Below detection limit of $1000 \mathrm{CFU}$ 
TOC/Abstract graphic
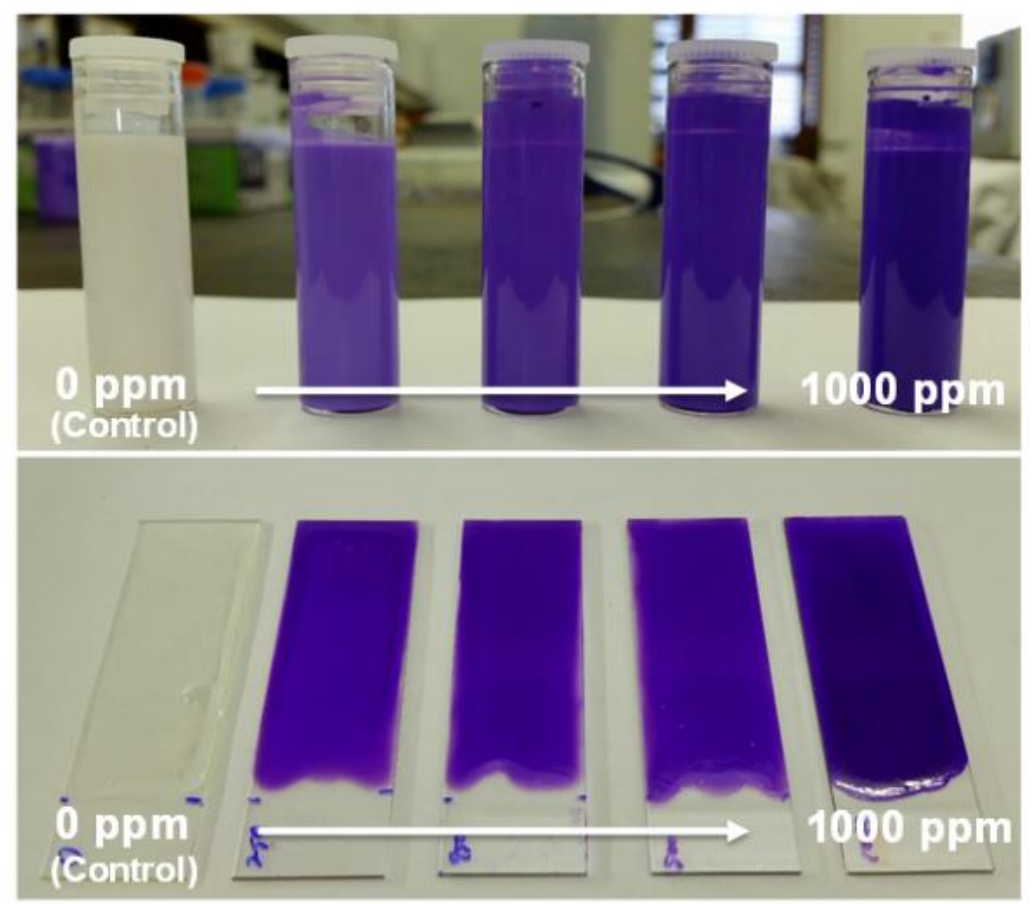